\title{
Effect of Financial Controls on Financial Stability of Micro Finance Institutions in Rwanda
}

\author{
Wilson Bashaija ", Pascal Nyiringango*, Mukulira Oliva*, Jacob Niyoyita Mahina \\ Department of Human Resource and Marketing, University of Rwanda, Kigali, Rwanda \\ Email address: \\ wilsonbashaija17@gmai.com (W. Bashaija) \\ ${ }^{*}$ Corresponding author \\ To cite this article: \\ Wilson Bashaija, Pascal Nyiringango, Mukulira Oliva, Jacob Niyoyita Mahina. Effect of Financial Controls on Financial Stability of Micro \\ Finance Institutions in Rwanda. Journal of Finance and Accounting. Vol. 8, No. 6, 2020, pp. 288-294. doi: 10.11648/j.jfa.20200806.15
}

Received: September 2, 2020; Accepted: November 24, 2020; Published: December 22, 2020

\begin{abstract}
The study sought to establish the effect of Financial Controls on Financial Stability of Micro Finance Institutions in Rwanda. The researcher used theory of financial controls. Research Design, Population, Sampling Frame and Size, and Data Processing and analysis were used during the study. The study shows a positive significant regression coefficient. This means that a unit change in Financial Controls brings about change in Financial Stability in the Micro Finance Institutions in Rwanda. The study thus rejects the null hypothesis conclude that there is significant relationship between Financial Controls and Financial Stability in the Micro Finance Institutions in Rwanda. Data analysis was descriptive statistics and inferential statistics using Statistical Packages for Social Sciences (SPSS) version 24. The analysis of variance (ANOVA) was checked to reveal the overall model of significance. The study recommends prudent policy measures on Financial Controls especially Asset management, financial system controls and Capital adequacy. Management recommends that quarterly reports are produced on time and ensure that external investors are able to monitor liquidity management and detect liquidity and credit risks exposed to their investments early enough. Government recommends that since all financial services players under MFI adhere to frequent reporting for better increase of financial management and efficient investment decisions.
\end{abstract}

Keywords: Financial Control, Financial Stability, Micro Finance Institution

\section{Introduction}

Tambunlertchai urged that the primary reasons for prudential regulation of depository institutions are to protect the country's financial system by preventing the failure of one institution from leading to the failure of others, and to protect small depositors who are not well-positioned to monitor the institution's financial soundness themselves [1]. In European Central Bank, the Financial Stability Review provides an overview of the possible sources of risk and vulnerability to financial stability in the euro area. Its aim is to promote awareness of issues that are relevant for safeguarding the stability of the euro area financial system, both within the financial industry and among the public. The risk-based approach to financial regulation that seem to be adopted by the Bank of Ghana shows that while there may be no major variances in the structure of MFS assets, they are differentiated by the structure of their liabilities (how assets and operations are funded) and the adequacy of qualifying capital in leveraging additional resources to fund operations. Bakilana, and Carpio urged that the potential tradeoff between regulation and stability in Kenya, a small open economy which is highly vulnerable to domestic and external shocks, but with a lightly regulated financial system and a fairly open capital account [2]. Financial sector reforms have undoubtedly strengthened Kenya's banking sector in the last decade or so, in terms of product offerings and service quality, stability and profitability. Currently, Rwanda's financial system is dominated by the banking sector. Generally, it has witnessed significant transformation. Changes have occurred with respect to the number of institutions, ownership structure and regulatory landscape. Protection [3]. The developments was supported by the Central Bank of Rwanda within the framework of systemic stability as supervision and regulation with efforts to ensure that only fit and proper institutions were granted banking license.

Microfinance Institutions helps to expand coverage, make 
financial services more affordable and secure, competitive and efficient by reducing transaction costs and protect customers' deposits and investment. The rapid growth of Microfinance has brought increasing calls for regulation. However complying with prudential regulations and the associated supervision can be costly for Microfinance Institutions creating doubt on their ability to comply with these regulations [4].

\subsection{Statement of the Problem}

Micro Finance Institution (MFI) deepens financial markets by raising institutional capital through pension funds, expanding bond and equity markets, and tapping international sources of capital and Safeguard financial system stability as an integral part of preserving monetary and macroeconomic stability in an economy [5]. Clients in the region of Eastern Europe and Central Asia (ECA) have higher repayment difficulties than in other regions due to the fact that unemployment is on the rise, remittances are down and there are unprecedented job losses while also the Microentrepreneurs 'profits are down and there are increasing problems to access liquidity. Microfinance Institutions helps to expand coverage, make financial services more affordable and secure, competitive and efficient by reducing transaction costs and protect customers' deposits and investment. The spiral effect is the undermining of the government's policy goal of promoting the financial stability and hence efficiency and access to financial services through MFI. There has been very little research into the regulation and supervision of MFIs and the impact of regulation and supervision on the development of the sector [6]. It is in this background that, the researcher will carry out the effect of Financial Controls on Financial Stability of Micro Finance Institutions in Rwanda.

\subsection{Theory of Financial Control}

Payments, financial instruments, accounting, control models, economic calculations, and related considerations, both within and outside of the organization, ought to be discussed in regard to inner characteristics but also possible effects [7]. It is noted that establishing the relationships between various activities and financial processes, from a financial control point of view, is a general and basic issue the theory of financial controls for organizations places a natural focus on the firms such that they are viewed from several latitudinal areas. The theory structure and financial control system works together [8].

The financial control theory is very relevant to the current study given that it assists in better understanding of the intricacies surrounding financial management in an organization. Theory [9] states that the treatment of financial theory should not ignore the real world problems that gave rise to its development in the first place in this sense, bridging the gap between theory and practice poses as a constant challenge to finance researchers and instructors. We need to discuss a theory's ability to fit actual data by examining empirical evidence for and against it [10]. Students should be correctly informed that theories are falsified only by discordant facts along with alternative theories and again, not by unrealistic assumptions. One of the most interesting aspects of this particular crash is that finance theory, not simply the practices of the financial services industry, has been directly blamed for the crisis. That is, some observers suggest that the crash itself was the result of bad or poorly applied theory.

Typically we say that all theories are based on a set of assumptions and they may be sometimes very crucial and unrealistic. Beyond any issues that may raise criticism, the two proposed (and subsequently validated) statements marked the starting point in founding modern finance. Consequently, financial theory saw new and extensive developments; recognizing the existence of shared dimensions, research in the field has been Management and Marketing. Subsequently, [11] pointed out that a firm operating under the assumptions of trade-off theory sets a target leverage ratio that it aims to achieve (hence also aiming for a target/optimal financial structure); the target leverage ratio can be determined by balancing the deadweight costs of bankruptcy with the tax deductions on interest earnings. Critical theory has hugely influenced social theory, largely as a result of the work of Habermas. It is complex so any summary here is highly simplified. Some essential characteristics of critical theory are its rejection of positivism as the sole arbiter and generator of knowledge largely because of its lack of self-reflection which leads it to reduce epistemology to a crudely.

\section{Conceptual Framework}

In line with the compliance used in previous studies on financial stability, this study proposes a conceptual framework to link the relationship between financial controls and financial stability of Micro Finance Institutions in Rwanda (which are the independent variables of the study) to financial stability (which is the dependent variable) in order to show the existing relationship. The independent variables are Audit process, Governance, Risk Management, and Financial Controls. The measurements for the individual constructs are also captured in the Conceptual framework.

\section{Research Design}

This study adopted a descriptive cross sectional design to answer the research questions. Descriptive survey is a method of collecting data by interviewing or administering a questionnaire to a sample of individuals which can be used when collecting information about peoples' attitudes, opinions, habits or any other social issues. Descriptive research is descriptions of the state of affairs as it exists [12]. The researcher was use of longitudinal survey design since the nature of research also relied on secondary data of published financial reports of Micro Finance Institutions in Rwanda. The data was for the last seven years namely year 
2010 to year 2016.

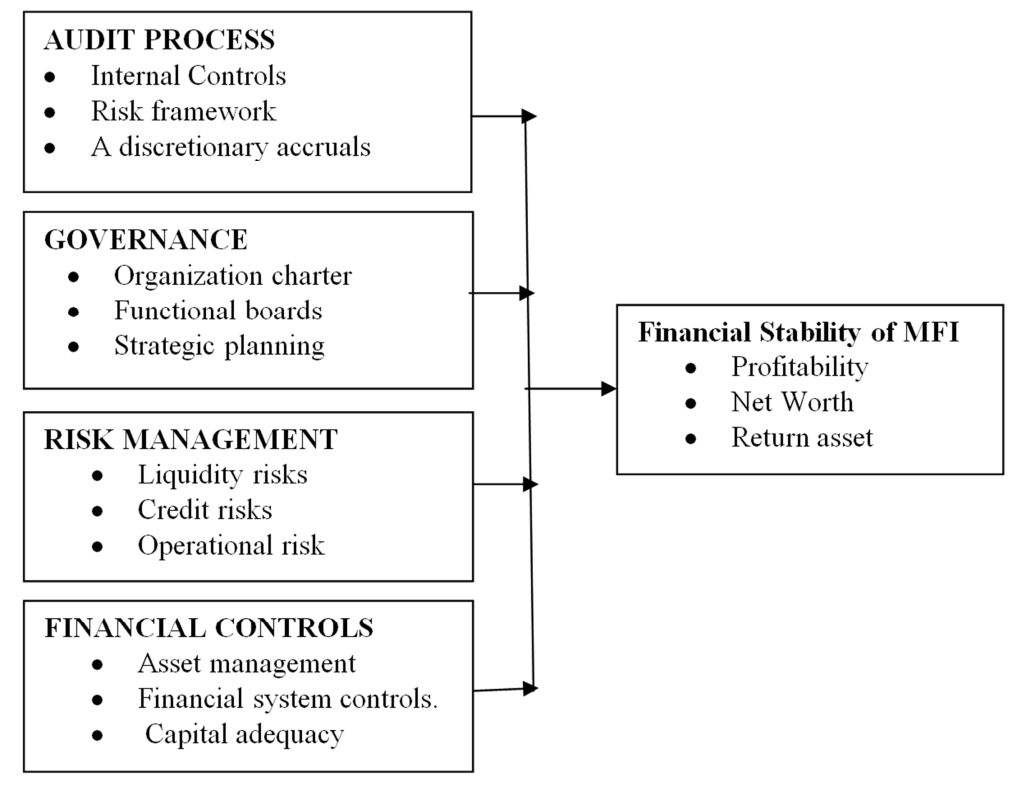

Figure 1. Conceptual Framework.

\section{Target Population}

A population as the entire group of people, events or things of interest that the researcher wishes to investigate [13]. The target population of this study was for senior managements of Micro Finance Institutions in Rwanda. Researcher, targeted nine MFI senior management (Chief executive officer, finance manager, credit manager, risk manager and senior accountant), seven MFI directors and twelve shareholders of the seven MFI directors and twelve shareholders of the MFI

\section{Sample Size and Sampling Technique}

The researcher adopted stratified random sampling technique where all units from the sampling frame have an equal chance to be drawn and to occur in the sample. Stratified random sampling [14]. The researcher used a sample representation of thirty (30\%) from each of the strata identified and to ensure equal representation which gave a sample of 152 respondents.

\section{Data Processing and Analysis}

The purpose of this study was to determine the effect of financial controls and Financial Stability of Micro Finance Institutions in Rwanda. It gives the empirical findings and results following the application of the variables using the techniques. The research findings are presented in the form of tables, charts and graphs. Financial Controls Financial controls were measured using eight items [15]. Each item was rated on a five points Likert scale with 1 being "strongly agree", and 5 being "strongly disagree". (a). Entity management periodically review accounting summaries. The result in Table 1 shows that the entity management periodically review accounting summaries to compare budgeted and actual amounts spent.

Table 1. Comparison between budgeted and actual amounts spent.

\begin{tabular}{|c|c|c|c|c|c|c|}
\hline Financial controls & Strongly disagree (\%) & Disagree (\%) & Not sure (\%) & Agree (\%) & Strongly agree $(\%)$ & Mean \\
\hline Financial controls (FC 1) & 0 & 7 & 20 & 51 & 22 & 3.88 \\
\hline Financial controls (FC 2) & 0 & 1 & 20 & 50 & 29 & 4.06 \\
\hline
\end{tabular}

The findings in Financial Controls, indicated that, majority $(73 \%)$ agreed and strongly agreed that the entity management periodically review accounting summaries to compare budgeted and actual amounts spent while $20 \%$ were not sure and $7 \%$ disagreed. Most of respondents confirm that that the entity management periodically review accounting summaries. Whose study revealed out that externally auditing the financial statements of the World Meteorological Organization (WMO) is traditionally exercised by members of the supreme public financial auditing body of the country chosen [16].

Respondents in Financial Controls in the above Table were asked to address whether the accounting system provide for accumulating and recording expenditures by activity/project and cost category shown in the annual budget. Majority (79\%), agree while, $20 \%$ were not sure and $1 \%$ disagreed with the statement. Based on results obtained above, accounting systems provides appropriate records and this is 
in line with the study [17].

Results indicated that majority $(84 \%)$ of respondents agreed and strongly agreed that the organization consider both internal and external sources when identifying relevant data to use in the operation of internal control, while $11 \%$ were not sure, $4 \%$ disagreed and $1 \%$ strongly disagreed the issue. Also study by Bass, and Dalal-Clayton Urged that
Internal controls ensure effective, systematic and coordinated implementation of the internal control framework, a Steering Committee has been established [18].

\section{(b). Periodic Reconciliations}

Accounting procedures require periodic reconciliations of accounts receivable and accounts payable with control accounts as indicated in Table 2 below

Table 2. Periodic Reconciliations.

\begin{tabular}{llllllll}
\hline Financial communication. & Strongly disagree (\%) & Disagree (\%) & Not sure (\%) & Agree (\%) & Strongly agree (\%) & Mean & Std. Deviation \\
\hline FC 4. & 1 & 6 & 15 & 53 & 24 & 3.94 & .852 \\
FC 5 & 0 & 2 & 14 & 52 & 32 & 4.14 & .740 \\
FC 6 & 0 & 2 & 17 & 52 & 29 & 4.07 & .747 \\
\hline
\end{tabular}

Respondents were asked, whether the accounting procedures require periodic reconciliations of accounts receivable and accounts payable with control accounts. Results fromTable above shows that, majority (77\%) agreed and strongly agreed, while $16 \%$ were not sure and $6 \%$ disagreed and $1 \%$ strongly disagreed. This entails that reconciliations are done regularly. This concurs with the study by Camilleri who asserted that the design of internal controls to fit an organization's needs begins with a risk assessment process [19].

Findings revealed that majority $(84 \%)$ of respondents agreed and strongly agreed, whether accounting supervisors frequently prepare reports or reconciliations to verify the accuracy of financial transactions processed, while $14 \%$ were not sure and $2 \%$ disagreed with the statement. This is in line with the study by Vallabhaneni who cited in that Supervises the accounts receivable and accounts payable functions, including such activities as the timely payment of all vendor invoices and expense vouchers, receiving and posting cash receipts, reconciling outstanding account balances, and the maintenance of accurate records and control reports.

Findings indicated that majority ( $81 \%)$ agreed and strongly agreed that the organization has transparency and accountability, it display performance results to all stakeholders, while $17 \%$ were not sure and $1 \%$ disagreed with the statement. This suggests that there is sound controls in place. This is in agreement with the study by Haliah, whose study revealed out that Effective accountability requires a statement of goals, transparent decision-making.

(c). An adequate up-to date cash book recording receipts and payments.

Results in Table 3. indicate that the organization maintains an adequate up-to date cash book recording receipts and payments.

Table 3. Organization maintain an adequate and up-to-date cashbook.

\begin{tabular}{lllllll}
\hline Financial controls & Strongly disagree (\%) & Disagree (\%) & Not sure (\%) & Agree (\%) & Strongly agree (\%) & Mean \\
\hline Financial Controls (FC 7) & 1 & 3 & 15 & 46 & 35 & 4.13 \\
Financial Controls (FC 8) & 1 & 3 & 16 & 50 & 30 & 4.03 \\
Financial Controls (FC 9) & 1 & 5 & 14 & 55 & 25 & 3.98 \\
\hline
\end{tabular}

The results in Table above indicated that majority (81\%) of respondents agreed and strongly agreed that organization maintain an adequate and up-to-date cashbook recording receipts and payments, while $15 \%$ were not sure and $4 \%$ disagreed and strongly disagreed with the statement. Therefore cashbook recording receipts and payments are done properly as per the above statements. This concurs with the study by Ross [21]. The procedures for recording your business expenses such as rent, electricity, telephone, insurance and motor vehicle expenses are essentially the same as those for recording purchases.

As shown, majority $(80 \%)$ of respondents agreed and strongly agreed that the accounting system provide for accrual of income and expenditures, while $16 \%$ were not sure and $3 \%$ disagreed and $1 \%$ strongly disagreed with the statement. This shows that accounting system provide for accrual of income and expenditures. The results also agree with the findings of Van Helden, Jan, and Ron Hodges [20, 22] who argued that the the accrual basis of accounting provides a better picture of a company's profits during an accounting period.

Respondents were asked to address whether department assets (property, equipment, supplies, etc.) that you believe are not adequately protected against theft or misuse. Results indicated that majority $(80 \%)$, agreed and strongly agreed, while $14 \%$ were not sure and $5 \%$ disagreed and $1 \%$ strongly disagreed with the statement. By and large, department assets are properly safeguarded. The result supports the findings by the study of Lu, Chang, Fan, and Zhu. Data loss prevention (DLP) is the practice of detecting and preventing confidential data from being "leaked" out of an organization's boundaries for unauthorized use.

(d). Assessment of the Sustainability of Current Funding levels.

The study in Table 4. sought to establish that Funding sources are evaluated annually to assess the sustainability of current funding levels. 
Table 4. Assessment of the Sustainability of Current Funding levels.

\begin{tabular}{lllllll}
\hline Financial controls. & Strongly disagree (\%) & Disagree (\%) & Not sure (\%) & Agree (\%) & Strongly agree (\%) & Mean \\
\hline Financial Controls (FC 10) & 0 & 7 & 25 & 44 & 24 & 3.84 \\
Financial Controls (FC 11) & 0 & 6 & 19 & 52 & 22 & 3.90 \\
Financial Controls (FC 12) & 0 & 10 & 15 & 53 & 22 & 3.86 \\
Financial Controls (FC 13) & 0 & 8 & 17 & 59 & 16 & 3.84 \\
\hline
\end{tabular}

Research findings indicated that majority (88\%) of respondents agreed and strongly agreed with whether Funding sources were evaluated annually, while $10 \%$ were not sure, $1 \%$ disagreed and $1 \%$ strongly disagreed with the statement. As indicated above, Funding sources were evaluated annually. The study concurs with the study by Johnson, Adams Becker, Estrada, and Freeman [23]. Whose study focused on a financial sustainability plan.

Results in Table above, indicated that majority $(80 \%)$ of respondents agreed and strongly agreed that Financial statements and reports are prepared for implementing unit, while $14 \%$ were not sure and $6 \%$ disagreed. This implies that financial statements and reports are prepared for implementing unit, as result management will take genuine decision. This concur with the study by Chan [24] who pointed out that Stock-taking or "inventory checking" is the physical verification of the quantities and condition of items held in an inventory or warehouse. This may be done to provide an audit of existing stock.

Respondents were asked to indicate whether the organization has transparency and accountability and it display performance results to all stakeholders. Findings show that majority (75\%) of respondents agreed and strongly agreed that, $15 \%$ were not sure while $10 \%$ disagreed with the statements. The results show that participants organization has transparency and accountability. This is in line with the study by Solomon [25], that Transparency is an indispensable aspect of accountability, effective accountability requires a statement of goals, transparent decision-making and relationships, and honest reporting of resource use and achievements, which can emphasize the honesty and efficiency with which resources are used or the impact and effectiveness of the work.

From Table above, indicated that majority (75\%) of respondents agreed and strongly agreed that Controls in place concerning the preparation and approval of transactions, ensuring that all transactions are correctly made and adequately explained, while $17 \%$ disagreed, $8 \%$ disagreed with the statement. Responses from participants show that there are sound controls in preparation and approval.

(e). Capital Adequacy Requirement to Banks

The capital adequacy ratio measures a bank's capital in relation to its risk-weighted assets. The capital-to-riskweighted-assets ratio promotes financial stability and efficiency in economic systems throughout the world.

Table 5. Importance of Capital Adequacy Requirement to Banks.

\begin{tabular}{llllllll}
\hline Financial Control & Strongly disagree (\%) & Disagree (\%) & Not sure (\%) & Agree (\%) & Strongly agree (\%) & Mean & Std. Deviation \\
\hline FC13 & 0 & 3 & 16 & 49 & 32 & 4.12 & .755 \\
FC14 & 1 & 16 & 62 & 21 & 4.04 & .623 \\
FC15 & 0 & 11 & 27 & 41 & 20 & 3.69 & .935 \\
\hline
\end{tabular}

From Table above, majority of respondents agreed and strongly agreed (81\%) that Capital Adequacy Requirement is Important to Banks while $16 \%$ of them were neutral and 3\% disagreed with the statement. This implies that Capital Adequacy is important to daily operations of the bank. This is in agreement with Almazari [26], revealed that Capital ratio indicates a bank's ability to withstand risks. Primarily, capital ratio helps a bank to withstand credit risk, liquidity risk, and operational risk. Generally, banks with high capital ratio are considered strong

Majority of respondents (63\%) agreed and strongly agreed that there is Challenges Faced the Implementation of Capital Adequacy Requirement, while 16\% were neutral and 1\% disagreed with statement. This concur with Černohorský, Šobotníková, and Teplý [27] Risk management, capital adequacy, implementation may affect profitability. A higher level of capital adequacy is needed to manage the higher level of risks identified in the banking activities.

Most of respondents (61\%) agreed and strongly agreed that there are Measures taken to Ensure Compliance with Capital Adequacy Requirement, while $27 \%$ were neutral and $11 \%$ disagreed with the statement. Nwogugu (2015) urged that various measures to ensure compliance with capital adequacy requirement such as cutting back on lending, market rights should be taken. This results to higher return on assets and equity revealing the need for capital regulation to the performance of banks and financial stability [28].

\section{ANOVA}

The results of ANOVA test reveal that Financial Controls has significant effect on Financial Stability in the Microfinance Institutions in Rwanda since the $\mathrm{P}$ value is actual 0.000 which is less than $5 \%$ level of significance. The results indicated that the overall model was significant $(\mathrm{F}$ $=65.512 ; \mathrm{P}=0.000)$. This implies that is, the independent variables were good joint explanatory variables. 


\section{Regression coefficient}

Financial Controls has a positive significant regression coefficient of 0.105 ( $p$-value $<0.05$ ). This means that a unit change in Financial Controls brings about a 0.105 change in Financial Stability in the Micro Finance Institutions in Rwanda.

\section{Effect of Financial Control on Financial Stability}

The study responded to the objective which sought to evaluate the effect of Financial Controls on Financial Stability of Micro Finance Institutions in Rwanda.

\section{Correlation for Financial Controls and Financial Stability}

The study determines whether Correlation for Financial Controls as independent variable can be able to explain Financial Stability. Pearson correlation shows coefficients between the independent variable Financial Controls and the dependent variable Financial Stability. The findings indicate a positive significant correlation of 0.226 since the level of significant is less than the set 0.05 .

\section{Research Hypothesis Testing}

There is no significant relationship between Financial Controls on Financial Stability in the Micro Finance Institutions in Rwanda.

\section{Recommendation}

The study recommends prudent policy measures on Financial Controls especially Asset management, financial system controls and Capital adequacy. Also the study recommends of policy development on member fund protection in relation to efficient market hypothesis and creation of robust financial market economy.

\section{References}

[1] Acharya, A. S., Prakash, A., Saxena, P., \& Nigam, A. (2013). Sampling: Why and how of it. Indian Journal of Medical Specialties, 4 (2), 330-333.

[2] Almazari, A. A. (2014). Impact of internal factors on bank profitability: Comparativestudy between Saudi Arabia and Jordan. Journal of Applied finance and banking, 4 (1), 125.

[3] Bakilana, A. M., \& Carpio, C. (2017). Building sustainable public sector capacity in a challenging context. Washington, D. C: World Bank.

[4] Bass, S., \& Dalal-Clayton, B. (2012). Sustainable development strategies: a resource book. London: Routledge.
[5] Camilleri, E. (2012). Project success: critical factors and behaviours. Gower Publishing, Ltd..

[6] Caprio, G. (2012). Handbook of key global financial markets, institutions, and infrastructure. New York: Academic Press.

[7] Černohorský, J., Šobotníková, P., \& Teplý, P. (2012). The challenges of Basel III for the Czech banking sector. In Proceedings of the 13th International Conference on Finance and Banking (pp. 33-44).

[8] Cook, T. D., Campbell, D. T., \& Day, A. (1979). Quasiexperimentation: Design \& analysis issues for field settings (Vol. 351). Boston: Houghton Mifflin. Fejerskov, A. M., Lundsgaarde, E., \& Cold-Ravnkilde, S. (2017). Recasting the 'New Actors in Development' Research Agenda. The European Journal of Development Research, 29 (5), 1070- 1085.

[9] Higson, A. (2003). Corporate financial reporting: Theory and practice. Sage.

[10] Klabbers, J. (2015). The EJIL Foreword: The Transformation of International Organizations Law. European Journal of International Law, 26 (1), 9-82.

[11] Lu, M., Chang, P., Li, J., Fan, T., \& Zhu, W. (2012). U.S. Patent No. 8,286,253. Washington, DC: U.S. Patent and Trademark Office.

[12] Mold, A., \& Bagiza, R. (2016). Building Productive Capacities for Regional and Global Competitiveness: The Case of the East African Community. In A. Gutowski, T. Knedlik, P.. Osakwe, I. Ramdoo, K. Wohlmuth (eds). Africa's Progress in Regional and Global Economic IntegrationTowards Transformative Regional Integration, 18, 183. LIT Verlag Münster.

[13] Myers, S. C. (2001). Capital structure. Journal of Economic perspectives, 15 (2), 81-102.

[14] Nwogugu, Michael C. I., Group-Decisions, Economic Policy and the Resolution of Non-Performing Loans (2015). Available at SSRN: https://ssrn.com/abstract $=2993160$ or http://dx.doi.org/10.2139/ssrn.2993160

[15] Östman, A., \& Augsten, M. (2009). Cancer-associated fibroblasts and tumor growth-bystanders turning into key players. Current opinion in genetics \& development, 19 (1), 67-73.

[16] Ross, D. F. (2015). Transportation Management. In Distribution Planning and Control (pp. 687-760). Springer US.

[17] Sekaran, U., \& Bougie, R. (2011). Research methods for business: A skill building approach. Chichester: John Willey \& Sons Ltd. 2010.

[18] Tambunlertchai, K. (2017). 9.1 Introduction 1. FINANCIAL INCLUSION, REGULATION, AND EDUCATION, 269.

[19] Van Greuning, H., Scott, D., \& Terblanche, S. (2011). International financial reporting standards: a practical guide. World Bank Publications.

[20] Bracci, E., Steccolini, I., Humphrey, C., Moll, J., Heald, D., \& Hodges, R. (2015). Will "austerity" be a critical juncture in European public sector financial reporting?. Accounting, Auditing \& Accountability Journal.

[21] Goforth, C. R. (2020). The Case for Preempting State Money Transmission Laws for Crypto-Based Businesses. Ark. L. Rev., 73, 301 . 
[22] Henrichsen, K. M. (2011). The effects of changes in EU emission trading scheme on the value of a gas fired power plant in Norway (Master's thesis).

[23] World Health Organization. (2012). Report of the sixteenth meeting of the WHO alliance for the elimination of blinding trachoma by 2020: Washington DC, USA, 14-16 May 2012 (No. WHO/PBD/GET/12.03). World Health Organization.

[24] Kumbhar, K. N., \& Bidve, H. (2016). Study of stock verification in college library. E-Journal of Library and Information Science, 3 (5), 26-35.

[25] Chepngetich, M. J. (2017). The influence of participatory communication in promoting accountability and transparency of constituency development fund in Emurua Dikirr Constituency. MA Unpublished Thesis. Nairobi University.

[26] Maaka, Z. A. (2013). The relationship between liquidity risk and financial performance of commercial banks in Kenya (Doctoral dissertation, University of Nairobi).

[27] Iqbal, A. (2012). Liquidity risk management: a comparative study between conventional and Islamic banks of Pakistan. Global journal of management and business research, 12 (5).

[28] Trujillo-Ponce, A. (2013). What determines the profitability of banks? Evidence from Spain. Accounting \& Finance, 53 (2), 561-586. 